\title{
Likely Impacts of Quota Policy on RMG Export from Bangladesh: Prediction and the Reality
}

\author{
Shamima Sultana (Corresponding author) \\ Department of Economics, Bangladesh University of Business and Technology (BUBT) \\ Mirpur, Dhaka-1216, Bangladesh \\ E-mail: shamima_quniv@yahoo.com \\ Md. Asraful Alam \\ Department of Mass Communication and Journalism, Jagannath University \\ Dhaka-1100, Bangladesh \\ E-mail: asraful29@yahoo.com \\ Arup Kumar Saha \\ Department of Marketing, University of Dhaka \\ Present Address: Kapp Ahl Far East Ltd., Dhaka-1212, Bangladesh \\ E-mail: arup.saha@kappahl.com \\ U. M. Ashek \\ Annesha Research Centre, 55 Shonargaon Janapath Road, Section 7, Uttara, Dhaka, Bangladesh \\ E-mail: umashek@annesha-style.com \\ Md. Abu Talha Sarker \\ The Independent, BEL Tower, 19, Road No.-1, BEL Tower, Dhanmondi, Dhaka-1205, Bangladesh \\ E-mail: abuts2009@gmail.com
}

Received: May 15, 2011

doi:10.5539/ijbm.v6n11p275
Accepted: July 7, 2011

URL: http://dx.doi.org/10.5539/ijbm.v6n11p275

The research is supported by the project "Study on the Likely Impacts of Quota Policy on RMG Export from Bangladesh” of Annesha Foundation, Dhaka, Bangladesh. (Sponsoring information)

\begin{abstract}
The Multi-fibre Arrangement (MFA) (Note 1) in global trade in apparels and textiles was phased out in December 2004. South Asian countries major concern was to prevent large-scale job losses due to liberalization and globalization. It was apprehended that the RMG sector of smaller countries especially Bangladesh will be adversely affected by losing a huge number of jobs, will face high competition from its low-cost competitor countries and will experience negative impact due to its high dependence on the United States and the European Union markets for its RMG products.

Despite the concern and fear of negative impact on in the aftermath of quota removal of RMG sector in Bangladesh appears with positive trends along with the substantial increasing rate of export amount, the number of jobs and industries and GDP's growth. In 2010, the sector keeps around 20 percent GDP growth of the country.

Keywords: Quota policy, Readymade garments, Export potential, Bangladesh

\section{Introduction}

From the very beginning Bangladesh is an agrarian economy having a very smaller industrial base. Before 80 's except jute there were not any noticeable heavy industry. Bangladesh depended for its exports earnings on a few primary commodities like raw jute, jute goods, tea and leather. But a great diversification in exports started after 1983. With the pace of time RMG has grabbed the position of jute and jute goods (Table-1). During 90's the performance of RMG industry has transformed Bangladesh economy from jute exporting to RMG exporting economy. Exports of RMG from Bangladesh have risen from about 4\% of its total exports in 1983-84 to about $80 \%$ in $2008-2009$. It Generates employment to about 3.5 million workers, $90 \%$ of these garment workers are female which is really a great contribution to Bangladesh's unemployment problem. The performance of RMG
\end{abstract}


industry has transformed Bangladesh economy from jute exporting to RMG exporting economy. From about $1.1 \%$ of Bangladesh's total export earning in 1981-82 within a time span of 20 years, the RMG industry currently accounts for about $80 \%$ (including woven and knitwear) of the country's total export earnings, making Bangladesh one of the 10 largest apparel exporters in the world.

During the world globalization of 80's the RMG industry has explored a new way of life. With the pace of time this promising sector has been contributing a remarkable amount in the total GDP of the country. Exports of RMG from Bangladesh have risen from about 4\% of its total exports in 1983-84 to about $80 \%$ in 2008-2009. About $78 \%$ of the annually foreign exchange earning comes from this sector. The highest number of employees about 3.5 million are engaged in the garment manufacturing sector. Around $90 \%$ of the garment workers are female mostly come from the underprivileged social classes which is really a great contribution in our industrialization process (Ali et.al., 2002; Bhattacharya and Rahman 1999).

The success of Bangladesh's RMG exports in a part attributable to availability of cheap labor, preferential treatment received from the European Union (EU) under the GSP (Generalised System of Preferences) scheme and substantial quotas available in the USA (as against quota restrictions imposed on its principal competitors, e.g. China, India, Pakistan, Sri Lanka, and Thailand). Bangladesh had the largest annual growth rate of almost 17 percent in garment export during the nineties (Islam et al., 2001; Siddiqi, 2004. This may be largely due to the lowest wage rate among all the countries in the region, in addition to other factors such as technological up gradation and trade union free EPZ. Although Bangladesh has no natural resources endowment like cotton but abundant cheap labor ensured competitive prices, and thus acted as a primary incentive to accelerate the rapid growth of RMG.

When the Multi-fibre Arrangement (MFA) in global trade in apparels and textiles has phased out in December 2004, it was predicted that the RMG sector of smaller countries especially Bangladesh will be adversely affected by losing a huge number of jobs and face high competition from its low-cost competitor countries. Bangladesh will experience negative impact due to its high dependence on the United States and the European Union markets for its RMG products. It was also predicted that the female workers ( 90 percent of the total work force) will face adverse consequences if the industries shut down in the aftermath of MFA period.

\section{Results and Discussion}

\subsection{Quota policy}

The rapid expansion of the garment industry within the last two decades has certainly given a wondering rapid job creation also has created fear about the possibility of similarly rapid loss of jobs. Once the quota system instituted under the MFA (Multi-fiber Arrangement) is abolished at the end of the year 2004. So the major concern of these South Asian countries is prevention of large-scale job losses due to liberalization and globalization.

The textile is governed by quota restrictions imposed by the developed countries including the USA, EU and Canada. The basic objective was to protect the domestic industry from competitive imports from the developing countries. The Multi Fiber Arrangement (MFA) governed all the quota restrictions in numerous sub-sectors of textiles. With the completion of the final round of WTO in 1994, the quota restrictions on textiles were found to be in conflict with the basic principles of WTO, which stressed upon removal of any no tariff barriers. As a consequence a new regime called the Agreement on Textiles and Clothing (ATC) replaced MFA.

The key objective of ATC is to phase out quota restrictions over a period of ten years. The MFA will cease to exist after December 31,2004. The process in which the developed countries are phasing out quotas according to their commitments with WTO is very interesting to evaluate, as the current level of liberalization is not in accordance with the committed volumes as well as categories of products which need to be integrated in the non quota trade regime. This raises serious concerns about the future of ATC.

\subsection{Impact of quota removal on Bangladesh}

South Asian countries are fully dependent on quota-based exports, and this is truer in the smaller countries with no resource endowments. The quota system was fashionised by industrialized countries under the MFA (Multi-Fiber Arrangement) in 1974 as a temporary agreement to protect their domestic garment industries from the onslaught of cheap imports from low wage countries. As a result of the quota restrictions, the Asian countries, which had used up their quota, initially established manufacturing platforms in other Asian countries, which were not in a position to fully utilize the available quota. Quota arrangements under MFA are due to terminate in a phased manner by the end of the year 2004. While it supposedly frees up the market for exporting countries to export ferments without quota restrictions, there is a great deal of apprehension that the jobs and incomes of a very large number of people in the garment industry would be in jeopardy when the exporting countries with resource endowment, like Bangladesh will be in a great recession where $95 \%$ is quota based exports (Table-2). Quota based exports was highest in Bangladesh and lowest was in Srilanka. Not only the number of jobs may come under threat but also the quality of jobs may suffer as price competitiveness places pressure on wage costs (Table-3). Among the South Asian countries workers gets highest wage in Pakistan and the productivity is also highest in Pakistan while Bangladeshi workers gets lowest wages but at the same time productivity is also lowest. However, share of wages is lowest in India (Table-3).

There may be less likelihood of a downward pressure on wage rates and work conditions, when competition is based on fashion and design rather than on costs. Such competition warrants firms to move into upper segments 
of the hierarchy of the apparel market or create new niches. The strategy involves higher marketing and selling efforts apart from considerations of quality and timeliness of delivery. In global commodity chain, given the lack of access to high fashion markets, producers may continue to face disadvantages. However, as borne out by the experiences of East Asian economies like Hong Kong, Korea and Taiwan, movement along the value chain and backward integration is feasible to an extent. A closer understanding of the experiences of these economies may offer valuable lessons for South Asian garment exporters.

\subsection{Prediction and the Reality}

In the MFA phase out era, many apprehensions were arisen for the south Asian RMG export countries especially for Bangladesh. Although the rapid expansion of the garment industry within the last two decades has certainly given a wondering rapid job creation, the fear about the possibility of similarly rapid loss of jobs has also appeared due to liberalization and globalization. A study projected that $0.35-0.4$ million workers $(0.31-0.36$ million female workers) will potentially loose their job. Around 1280 production units will be closed and approximately $40 \%-50 \%$ production will be reduced in cutting and making prices in the MFA post era. Similarly, the macroeconomy of the country like export earnings, foreign exchange reserve, export growth will also be affected that would lead to reduce the capacity of the Bangladesh government in poverty reduction (Ali et. al., 2002). In the abolition of quota, Bangladesh may likely lag behind in keeping its market share to the efficient competitors such as India, Thailand, Vietnam, Indonesia, Republic of Korea, Mexico, Turkey.

Bangladesh could lose their market share and it would even fall down due to low productivity, long lead time, weak competitive strength, fragile forward and backward linkage and so on. So a country like Bangladesh that highly dependent on export-oriented readymade garment sector for investment, employment, foreign currency earning and growth potentials, will face a great challenge towards MFA phase put on the export-oriented apparel sector. The ILO is naturally concerned with the potential loss of employment and deterioration of job quality in the developing countries in South Asia (Joshi, 2002). It was also predicted that the vast single market of United States and the European markets of Bangladeshi garment products will face tough competition with China, Thailand, Pakistan, Sri Lanka, Mexico, Cambodia, Vietnam as well as India in the aftermath of MFA period. At the beginning of quota free regime, experts were also feared that Bangladesh will not be able to convince their overseas buyers as their reliable sources due to a handful of industries that provide RMG goods in the world market. Due to the severe crises of inadequate backward linkage of industries, excessive dependency on imported raw materials and wide length of 'lead time' will be the great challenges for Bangladeshi RMG sector in the post MFA era.

The fear was also arisen due to the act of USTDA (US Trade and Development Act 2000) 2000. The act gives duty and quota free access (exporting textile and apparel products) to 72 countries of Caribbean Basin (CBI) and the Sub Saharan Africa (SSA) to the US market (Bhattacharya \& Rahman 2000). Since US is the second largest (Table- 7) RMG exporting market of Bangladesh, the USTDA 2000 might affect the sector adversely in the quota phase out period.

The inclusion of social clause introduced into WTO (World Trade Organization) charter appeared with fear for the trading system of developing countries like Bangladesh. According to the clauses, restriction will be imposed on imports of products from the countries not fulfilling the minimum labor standard, environment, and employment rules. (International Herald Tribune 29 July 1996, 11: cited in Robbani, 2000) "Compliance with these social issues may erode the country's low-cost advantage and non-compliance might spell ruin" (Robbani, 2000).

Despite the concern and fear of negative impact on in the aftermath of quota removal, the whole scenario of RMG sector in Bangladesh appears with positive trends. Bangladesh mainly exports garment, knit and woven goods including shorts, trousers, shirts, sweaters, blouses, skirts, tea-shirts, jackets, sports attire and many more casual and fashion items with the changing times. Despite removing privileged quota system, the number of RMG industries rose up over the periods (Rahman et.al., 2008). As per the statistics of BGMEA (Bangladesh Garment Manufacturers and Exporters Association), an apex trade body of the country, that the RMG export was 31.57 million US\$ in 1983-84 and goes up to 12347.77 million US\$ in 2008-09. RMG export of Bangladesh was $3.89 \%$ of total export in 1983-84 while in 2008-09 it was about $80 \%$ (Table-4). After quota removal in 2004 average more than $16 \%$ growth were observed from 2004-05 to 2008-09 and during this period total export growth rate were also more than $15 \%$. There were negative growth rate in 1985-86, 1990-91 and 2001-02. In 1985-86 and 2001-02 growth rate was negative due to decrease in RMG export while in 1990-91 negative growth was due to decrease in total export and this was probably due to severe flood in 1988 (Table-4). Raw jute was $0.95 \%$ and jute goods was $2.4 \%$ of total export while woven garments and knitwear was $53.6 \%$ and $22.1 \%$ respectively of the total export in 2008-09 (Table-1). There were just four industries in 1983 in RMG sector whereas the number has increased at around 5,000 in 2009 (Table-5).

Table- 5 shows that the number of garment industries has sharply increased over the periods from 1984 to the year of 2009. There were only 384 industries in 1983-84 and the number has continuously increased over the periods and reached at around five thousands in year of 2008-09. About 1000 factories were established after 2004. More than 1 million workers entered into this sector. Factory growth rate was $4 \%$ while the workers growth rate was about $10 \%$ (Table-5).

Table 6 illustrates a comparative scenario between the pre phase out completion year (2004) and the first post 
phase out of MFA year (2005) of apparel exports. It is clearly shown that Bangladesh exports US\$6.81 billion in 2005 , a growth rate of 2.6 percent over the previous year though the growth rate of china was $44.4 \%$, India $32.2 \%$, Cambodia $10.6 \%$ and Indonesia $7.3 \%$ (Table-6). The RMG sector is witnessed the highest number of foreign currencies after the amount of overseas employees of Bangladesh, though the economic meltdown of the world especially in the developed countries. The devastating recession does not touch the country's economy due to the great contribution of these two sectors. The readymade garment has been appeared increasingly up-wards trend (Rahman et. al., 2008). The contribution of the sector occupied the larger part of the country's GDP growth. In 2010, the sector keeps around 20 percent GDP growth of the country (BGMEA and BKMEA database).

The RMG sector accommodates the highest number of employees around 4.0 million people which includes skilled, half-skilled, unskilled and uneducated workers. About 80 percent of the workers are female come from the remote area of the country. The sector plays a significant role in both micro and macro level development of the country changing the standard of life and increasing per capital income. To see the rosy prospects of the sector, new entrepreneurs are coming to invest with their huge amount of money.

The European Union and the United States remained main exports markets of the country followed by Canada, Japan and Australia (Table-7). Bangladesh exports its garments product to around 90 countries across the world that include USA, Germany, Canada, France, United Kingdom (UK), Spain, Belgium, Netherlands, Italy etc. At present, a lot of possible scopes of market expansion of Bangladeshi RMG goods has been made all over the world especially to Russian Federation, South Africa, Taiwan and some countries of south American continent.

Being behind China, Vietnam and Indonesia, Bangladesh has achieved the fourth position in apparel exporting countries to the United States (US) market in 2010. According to the Commerce Wing report of Bangladesh Embassy in Washington DC, Bangladesh exported \$409 million worth of RMG products in August 2010 while the same amount in August 2009 was only \$289 million, marking a spectacular 41.5 per cent growth. Compared to the Bangladesh's monthly August, 2010 growth of 41.5 per cent, exports from China grew by 28.81 per cent, Vietnam by 24.59 per cent, Indonesia by 23.84 per cent, India by 13.12 per cent and Cambodia by 27.38 per cent, as per data released by US International Trade Commission (USITC) (The Financial Express, October 22, 2010). It is expected that the earning of Bangladeshi RMG sector will go up to US\$ 30-35 billion within a couple of years if a proper infrastructure, smooth port facilities, labour unrest, strikes, improvement of law and order situation and uninterrupted power supply can be ensured (The Financial Express, January 12, 2011).

Though there is insufficiency of backward linkages in the sector, a number of backward linkages have been established to mitigate the problems. As part of RMG, trade and commerce sector like Home Textile, Handloom, Grameen Check, Terry Towel have been expanding in both domestic and export markets. Recently, a new concept- 'Public Private Partnership' (PPP) has been developed to further augment of the sector which acts in lobbying, formulating rules \& regulations and escalating market share in the sub-continent.

In the late 1970s and early 1980s intermediate buyers began to shift sources of RMG products from neighboring countries like Bangladesh. Abundant cheap labor in Bangladesh ensured competitive prices, and thus acted as a primary incentive to accelerate the rapid growth of RMG in Bangladesh. RMG industry has transformed Bangladesh from a jute exporting country into what is primarily a garment exporting economy. From about $1.1 \%$ of Bangladesh's total export earning in 1981-82, within a time span of 20 years, the RMG industry currently accounts for about $76 \%$ (including woven \& knitwear) of the country's total export earnings, making Bangladesh one of the 12 largest apparel exporters in the world (Table-1). During the world globalization of 80's the RMG industry has explored a new way of life. With the pace of time this promising sector has been contributing a remarkable amount in the total GDP of country. It is expected that the earning of Bangladeshi RMG sector will go up to US\$ 30-35 billion within a couple of years. The success of Bangladesh's RMG exports in a part attributable to availability of cheap labor, preferential treatment received from the European Union (EU) under the GSP scheme: and substantial quotas available in the USA (as against quota restrictions imposed on its principal competitors, e.g. China, India, Pakistan, Srilanka, and Thailand.

2.4 Challenges

In spite of having many positive consequences of post MFA impact in Bangladeshi RMG sector, the country is to face many harsh realities and challenges like severe shortage of backward linkage, raw materials, limited market, political unrest etc. In this position their way of survival may be diversifying of present garments trade, developing infrastructue, establishing strong backward and forward linkage and enhancing the product quality.

Handling labor unrest is one the major challenges for the entrepreneurs of this sector. There are many reasons behind the labor unrest in RMG sector especially to the lower wages. Recently a new salary structure of the RMG sector has been introduced in November, 2010. Garment workers have been getting their wages under the new pay scale. Since the growing cost of living in the capital, workers, RMG related non-government organizations, human rights groups sometimes demand for the increase of wages. However, it is also the fact that Bangladesh has placed its position in the competitive market for the cheap labor cost in apparel manufacturing. 'The workers' fight against unsustainably lower wages in RMG is understandable given the growing cost of living in Dhaka. Nevertheless, they must accept the fact that it is the cheap labour cost that has made Bangladesh a competitive place for apparel manufacturing (Islam, 2010).

Despite having cheap cost of labor advantage, Bangladesh cannot go ahead to its expected position in the 
competitive global market due to lack of requisite infrastructure, uninterrupted supply of energy. As a result, per unit production cost of RMG products have been growing more than most of its competitors. And the arch opponents of Bangladeshi RMG products especially India, China, Indonesia and Brazil increasingly took the opportunity in the international market. The succeeding government of Bangladesh partially avoided their liability towards the pressing issue and took the double-standard policy when they are in power and out of power.

The sufficient supply of raw materials for RMG product is one of biggest challenges for Bangladesh garment industry. Bangladesh depends for its raw materials mainly on China and India. In recent times, China is gradually reducing the production of finished goods of RMG along with paying concentration to boost up its raw materials business in place of garment products, according to its yarn policy. Besides, they are increasing the price of raw materials with their sweet wills. That is why the garment industries of Bangladesh are facing a new challenge for it.

Though the number of industries along with the workers is rapidly has been increased over the periods, ensuring a safe, secured and healthy working environment is another challenge for maintaining the code of conduct, protecting human rights, and meeting social compliances. Limiting working hours, compensating for extra work, paying minimum basic wage for time being, providing training for unskilled workers should be ensured for the betterment of the RMG sector of the country. Zafour 2009 finds out some problems in garment industries in Bangladesh which are mentioned bellow (Table-8).

Zafour 2009 also found some secondary problems viz. middle man affect, sluggish business linkage, unloading (RM) takes time, time consuming schedule, communication gap, dependency on foreign market, trade block, credit problem etc.

\subsection{The way out to survive}

Bangladesh has already passed six years without any major setback in the post MFA era. However, the whole scenario of post MFA era of the sector is completely different than that was predicted earlier. The amount of apparel export has consequently increased over the years. The country increased its export along with the substantial increasing rate of export amount, the number of jobs and industries and GDP growth.

Abolition of quota in apparel manufacturing and exporting also brings many implications in the field of global trade in apparels. Garment exporting countries now have a new opportunity to export their products without any restriction, importers have open sourcing, retailers have competitive price, and consumers have lower prices and broader choices. These opportunities have boosted the world apparel trade to a peak at about US $\$ 275.6$ billion in 2005 from US\$258.2 billion in 2004 and US\$228.7 billion in 2003. It is expected that the earning of Bangladeshi RMG sector will go up to US\$ 30-35 billion within a couple of years. In spite of having a lot of potentialities of RMG sector in Bangladesh, it is still facing many challenges which needs to be addressed are as follows:

\section{i. $\quad$ Product Diversification}

RMG production is concentrated in a relatively limited range of products such as shirts, T-shirts, trousers, and shorts. To be internationally competitive, Bangladesh needs to expand its product range and should begin producing fashion-wear and higher value-added items. Product diversification is essential to meet the challenges of the post MFA world. Evidence suggests that Bangladeshi entrepreneurs are already shifting to higher-value knitwear products.

Policy makers must recognize that sufficient capacity building is required for such diversification, which involves improving skills such as fashion design and cutting as well as upgrading technology. The design and color of the RMG product should be maintained with the keeping pace of modern styles and fashion. New markets should be explored in other untouched area along with the existing exporting countries.

The quality of product should be developed with the changing circumstances of the global consumers. Through establishing the steady and dependable sources for the fabric division, we can throw a challenge to our arch-rival in the international market with our diversified exporting products. To reduce the lead time, E-commerce system should be started in the every part of the sector as early as possible.

\section{ii. Backward Linkage}

A fundamental constraint on the potential of the RMG industry is the general absence of backward linkages. In their absence, the country's local value addition has so far been only 25-30 percent of gross exports. The RMG industry is currently heavily dependent on raw materials. A report of World Bank shows that Bangladesh imports 2-3 billion yards of fabric yearly to meet her raw material demand (World Bank, 1999). Nonetheless, Bangladesh's excessive dependence on imported raw materials has adversely affected its competitiveness by increasing the lead time and cost of production. This is something, which has to be overcome in what promises to be a highly competitive post MFA phase. The lead time from the order date to the shipment date in Bangladesh is between 120 and 150 days, compared to 19-45 days in India and Srilanka. For some countries, the lead time is only 12 days (Textile Asia, June 1999, p-61). Unless Bangladesh manages a substantial reduction in its lead time, domestic production of quality fabrics for export will be left in a very disadvantageous position.

The country could save considerable foreign exchange by increasing domestic production of yarn and fabrics. Establishment of backward linkages, especially the production of yarn, can reduce the cost of production, high interest rates for a certain period (three months), large transport cost, bribes, commissions, and fees for 
middleman service involved in customs clearance, etc. Large scale investments in backward linkage industries may require considerable inflows of FDI and a pro-active government policy in terms of providing the finance for such investment to domestic entrepreneurs. What is badly needed is a policy of promoting smaller and labor intensive units whereby the necessary backward linkages take place without heavy investments.

iii. Productivity Increase

It is clear form the discussion so far that one issue facing the RMG industry in Bangladesh is the slow rate of increase in productivity, and the gap that exists between Bangladesh and other competitors in this regard. There is also scope for capacity building in different types of skills and processes. Among the South Asian countries wage is lowest in Bangladesh and productivity is also lowest so consequently the share of wages is also comparatively higher (Table-2). Minimum wages of workers were also went up in the aftermath of MFA.

The aim should be to move the industry up to a different regime, wherein competition is based on higher productivity, an improved working environment, and backward and forward linkages to meet the new challenges of the post-MFA era. A more concerted action plan is needed in this regard. Uninterrupted year long production should be ensured for the sustainable development of RMG sector in Bangladesh. Labor unrest must be mitigated in any way for uninterrupted and optimum production round the year.

iv. Infrastructural Development

To boost up the RMG sector, some infrastructural and logistic supports such as uninterrupted gas and electricity supply, better transportation, smooth loading and unloading process in the port, peaceful environment, establish fashion institute and fashion house, modernizing banking system and decreasing the rate of bank loan will be needed.

\section{References}

Ali, AKM Masud; Ali, AKM Mustaque \& Sarker, Ratan. (2002). The RMG sector of Bangladesh and its female workers: Awaiting a new global movement, Incidin Bangladesh. [Online] Available: http://www.docstoc.com/docs/48643210/The-RMG-Sector-of-Bangladesh-and-Its-Female-Workers.

BATEXPO $\left(20^{\text {th }}\right)$ Handbook. (2009). Bangladesh Garment Manufacturers and Exporters Association (BGMEA), Dhaka.

BGMEA database. [Online] Available: http://www.bgmea.com.bd/home/pages/marketaccessandtariffs

Bhattacharya, D., \& M. Rahman. (1999). Female Employment Under Export-Propelled Industrialization: Prospects for Internalizing Global Opportunities in Bangladesh's Apparel Sector, UNRISD Occasional Paper.

Bhattacharya, D., \& Rahman, M. (2000). Dialogue on "Implementation of WTO-ACT: Current Status and Implications for Bangladesh" (Draft), Sept. 30, Center for Policy Dialogue, Dhaka, p. 31.

BKMEA database (Bangladesh Knitwear Manufacturers and Exporters Association (BKMEA) [Online] Available: http://www.bkmea.com/facts_figures.php

EPB [atabase. Anline] Available:

http://www.epb.gov.bd/index.php?NoParameter\&Theme=default\&Script=detailsexportdta

Islam, M. Shahidul. (2010). RMG sector: Challenges versus opportunities. The Daily Star, Thursday, August 5. [Online] Available: http://www.thedailystar.net/newDesign/news-details.php?nid=149400

Islam, S. (2001). The textile and clothing industry of Bangladesh in a changing world economy, Dhaka University Press Ltd, Dhaka.

Joshi, Gopal. (2002). Garment industry in South Asia Rags or riches?. South Asia Multidisciplinary Advisory Team (SAAT), New Delhi. [Online] Available: http://www.scribd.com/doc/17704903/Garment-Industry.

Khundaker, Nasreen. (2001). Productivity, Competitiveness and job Quality in Garment Industry in Bangladesh. A discussion paper prepared for the Sub-regional Meeting on Productivity, Comparativeness and Job Quality in Garment Industry in South Asia, Kathmandu 25-26 September 2001.

Rahman, Mustafizur; Bhattacharya, Debapriya; Moazzem \& Khondaker Golam. (2008). Bangladesh Apparel Sector in Post MFA Era. Centre for Policy Dialogue, Dhaka.

Robbani, M Golam. (2000). World trade organization and the readymade garment industry of Bangladesh: a critical analysis. Journal of Bangladesh Studies, 2 (2), 16-27.

Siddiqi, H. G. A. (2004). The Readymade Garment Industry of Bangladesh. The University Press Limited, Dhaka.

Textile Asia. (1999). June 1999, p-61.

The Financial Express. (2010). RMG export growth in US highest among competing countries. Dhaka, Friday October 22, 2010.

The Financial Express. (2011). RMG sector earning may reach $\$ 30-35 b$ in $4-5$ yrs, January 12, 2011. [Online] Available: http://www.thefinancialexpress-bd.com/more.php?news_id=122728\&date=2011-01-13

World Bank. (1995). Bangladesh From Stabilization to Growth. WB Country Report, Washington DC, p-77.

Zafour, Abu. (2009). Problems and Prospects of Garments Industries in Bangladesh. [Online] Available: http://www.reportbd.com/articles/190/1/Problems-and-Prospect-of-Garments-Industry-in-Bangladesh/Page1.htm 
1.

Note

Note 1. MFA: Multi-fiber Arrangement

"An international trade agreement on textile and clothing that was active from 1974 till 2004. The agreement imposed quotas on the amount that developing countries could export in the form of yarn, fabric and clothing to developed countries". (www.investopedia.com)

Table 1. Export of Major products from Bangladesh and their share (\%) in total export

\begin{tabular}{|l|l|l|l|l|l|}
\hline \multirow{2}{*}{$\begin{array}{l}\text { Export of Major Products } \\
\text { from Bangladesh }\end{array}$} & \multicolumn{5}{|c|}{ \% of Total Export } \\
\cline { 2 - 6 } & $1972-73$ & $1981-82$ & $1990-91$ & $1999-00$ & $2008-09$ \\
\hline Jute goods & 51.4 & 46.5 & 16.9 & 4.6 & 2.4 \\
\hline Raw jute & 38.5 & 16.3 & 6.1 & 1.3 & 0.95 \\
\hline Woven garments & NA & 1.1 & 42.8 & 53.6 & 37.11 \\
\hline Knitwear & NA & NA & 7.6 & 22.1 & 42.01 \\
\hline Frozen food & 0.9 & 8.5 & 8.3 & 6.0 & 2.92 \\
\hline Leather & 4.6 & 10.1 & 7.8 & 3.4 & 1.14 \\
\hline Tea & 2.9 & 6.1 & 2.5 & 0.3 & 0.08 \\
\hline Chemical products & 0.9 & 1.1 & 2.6 & 1.6 & 2.71 \\
\hline Others & 0.9 & 10.4 & 5.4 & 7.1 & 10.68 \\
\hline
\end{tabular}

Source: Bangladesh Garment Manufacturers and Exporter's Association, January, 2011

Table 2. Quota-based exports in South Asian countries

\begin{tabular}{|l|l|}
\hline COUNTRIES & QUOTA-BASED EXPORTS (\%) \\
\hline Bangladesh & 95 \\
\hline Pakistan & 90 \\
\hline Nepal & 80 \\
\hline India & 73 \\
\hline Srilanka & 62 \\
\hline
\end{tabular}

Source: Sub-regional Meeting on Productivity, Competitiveness and job Quality in Garment industry in South Asia, Kathmandu 25-26 September 2001.

Table 3. Productivity and wages in South Asian countries

\begin{tabular}{|l|l|l|l|}
\hline Countries & Wages & Productivity & Share of wages (\%) \\
\hline Pakistan (1991) & 1553.5 & 3236.1 & 48.0 \\
\hline Srilanka (1993) & 653.1 & 1876.1 & 34.8 \\
\hline India (1994) & 627.5 & 3146.1 & 19.9 \\
\hline Bangladesh (1992) & 340.9 & 890.1 & 38.3 \\
\hline Nepal & - & - & - \\
\hline
\end{tabular}

Source: Islam, 2001 
Table 4. RMG Exports of Bangladesh: A comparative scenario

\begin{tabular}{|c|c|c|c|c|c|}
\hline Year & $\begin{array}{c}\text { RMG Export (M } \\
\text { US\$) }\end{array}$ & $\begin{array}{l}\text { RMG } \\
\text { Export } \\
(\%)\end{array}$ & $\begin{array}{l}\text { Total } \\
\text { Export } \\
(\mathrm{M} U S \$)\end{array}$ & $\begin{array}{l}\text { Total } \\
\text { Export } \\
(\%)\end{array}$ & $\begin{array}{l}\text { RMG Export as a } \\
\% \text { of total Export }\end{array}$ \\
\hline $1983-84$ & 31.57 & - & 811.00 & - & 3.89 \\
\hline $1984-85$ & 116.2 & - & 934.43 & - & 12.44 \\
\hline $1985-86$ & 131.48 & 13.15 & 819.21 & -12.33 & 16.05 \\
\hline $1986-87$ & 298.67 & 127.16 & 1076.61 & 31.42 & 27.74 \\
\hline $1987-88$ & 433.92 & 45.28 & 1231.2 & 14.36 & 35.24 \\
\hline 1988-89 & 471.09 & 8.57 & 1291.56 & 4.90 & 36.47 \\
\hline $1989-90$ & 624.16 & 32.49 & 1923.70 & 48.94 & 32.45 \\
\hline $1990-91$ & 866.82 & 38.88 & 1717.55 & -10.72 & 50.47 \\
\hline $1991-92$ & 1182.57 & 36.43 & 1993.90 & 16.09 & 59.31 \\
\hline 1992-93 & 1445.02 & 22.19 & 2382.89 & 19.51 & 60.64 \\
\hline 1993-94 & 1555.79 & 7.67 & 2533.90 & 6.34 & 61.40 \\
\hline 1994-95 & 2228.35 & 43.23 & 3472.56 & 37.04 & 64.17 \\
\hline $1995-96$ & 2547.13 & 14.31 & 3882.42 & 11.80 & 65.61 \\
\hline $1996-97$ & 3001.25 & 17.83 & 4418.28 & 13.80 & 67.93 \\
\hline $1997-98$ & 3781.94 & 26.01 & 5161.20 & 16.81 & 73.28 \\
\hline 1998-99 & 4019.98 & 6.29 & 5312.86 & 2.94 & 75.67 \\
\hline 1999-00 & 4349.41 & 8.19 & 5752.20 & 8.27 & 75.61 \\
\hline $2000-01$ & 4859.83 & 11.74 & 6467.30 & 12.43 & 75.14 \\
\hline 2001-02 & 4583.75 & -5.68 & 5986.09 & -7.44 & 76.57 \\
\hline 2002-03 & 4912.09 & 7.16 & 6548.44 & 9.39 & 75.01 \\
\hline 2003-04 & 5686.09 & 15.76 & 7602.99 & 16.10 & 74.79 \\
\hline 2004-05 & 6417.67 & 12.87 & 8654.52 & 13.83 & 74.15 \\
\hline 2005-06 & 7900.80 & 23.11 & 10526.16 & 21.63 & 75.06 \\
\hline 2006-07 & 9211.23 & 16.59 & 12177.86 & 15.69 & 75.64 \\
\hline 2007-08 & 10699.80 & 16.16 & 14110.80 & 15.87 & 75.83 \\
\hline 2008-09 & 12347.77 & 15.40 & 15565.19 & 10.31 & 79.33 \\
\hline
\end{tabular}

Source: BGMEA \& EPB database 
Table 5. Growth of RMG industry and employment

\begin{tabular}{|c|c|c|c|c|}
\hline Year & $\begin{array}{c}\text { Number of garment } \\
\text { factories }\end{array}$ & $\begin{array}{c}\text { Factory Growth } \\
\text { Rate }(\%)\end{array}$ & $\begin{array}{l}\text { Workers } \\
\text { (Million) }\end{array}$ & $\begin{array}{l}\text { Workers Growth } \\
\text { Rate (\%) }\end{array}$ \\
\hline $1984-85$ & 384 & - & 0.12 & - \\
\hline $1985-86$ & 594 & 54.69 & 0.20 & 66.67 \\
\hline 1986-87 & 629 & 5.89 & 0.28 & 40.00 \\
\hline $1987-88$ & 685 & 8.90 & 0.31 & 10.71 \\
\hline 1988-1989 & 725 & 5.84 & 0.32 & 3.23 \\
\hline $1989-90$ & 759 & 4.69 & 0.34 & 6.25 \\
\hline 1990-91 & 834 & 9.88 & 0.40 & 17.65 \\
\hline 1991-1992 & 1163 & 39.45 & 0.58 & 45.00 \\
\hline 1992-93 & 1537 & 32.16 & 0.80 & 37.93 \\
\hline 1993-94 & 1839 & 19.65 & 0.83 & 3.75 \\
\hline 1994-95 & 2182 & 18.65 & 1.20 & 44.58 \\
\hline $1995-96$ & 2353 & 7.84 & 1.29 & 7.50 \\
\hline 1996-97 & 2503 & 6.37 & 1.30 & 0.78 \\
\hline $1997-98$ & 2726 & 8.91 & 1.50 & 15.38 \\
\hline 1998-1999 & 2963 & 8.69 & 1.50 & 0.00 \\
\hline $1999-2000$ & 3200 & 8.00 & 1.60 & 6.67 \\
\hline $2000-2001$ & 3480 & 8.75 & 1.80 & 12.50 \\
\hline $2001-2002$ & 3618 & 3.97 & 1.80 & 0.00 \\
\hline $2002-2003$ & 3760 & 3.92 & 2.00 & 11.11 \\
\hline $2003-2004$ & 3957 & 5.24 & 2.00 & 0.00 \\
\hline $2004-2005$ & 4107 & 3.79 & 2.00 & 0.00 \\
\hline $2005-2006$ & 4220 & 2.75 & 2.20 & 10.00 \\
\hline $2006-2007$ & 4490 & 6.40 & 2.40 & 9.09 \\
\hline $2007-2008$ & 4743 & 5.63 & 2.80 & 16.67 \\
\hline $2008-2009$ & 4825 & 1.73 & 3.10 & 10.71 \\
\hline
\end{tabular}

Source: BGMEA \& EPB database

Table 6. RMG Export of some selected Asian Countries

\begin{tabular}{|l|l|l|l|}
\hline \multirow{2}{*}{ Countries } & \multicolumn{2}{|l|}{ Export in billion US\$ } & $\begin{array}{l}\text { Percentage change in } \\
\text { 2005 over 2004 }\end{array}$ \\
\cline { 2 - 4 } & 2004 & 2005 & 44.4 \\
\hline China & 25.59 & 36.95 & 32.2 \\
\hline India & 5.52 & 7.3 & 10.6 \\
\hline Cambodia & 2.16 & 2.39 & 7.3 \\
\hline Indonesia & 4.22 & 4.53 & 3.0 \\
\hline Sri Lanka & 2.67 & 2.75 & 2.6 \\
\hline Bangladesh & 6.64 & 6.81 & -1.3 \\
\hline Pakistan & 2.38 & 2.35 & \\
\hline
\end{tabular}

Source: Rahman at al., 2008

Table 7. Markets of RMG export

\begin{tabular}{|l|l|l|l|}
\hline Year & Countries & Export & Percent (\%) \\
\hline \multirow{5}{*}{$2008-2009$} & 7218.23 & 58.46 \\
\cline { 2 - 4 } & EU & 3693.40 & 29.91 \\
\cline { 2 - 4 } & Canada & 587.05 & 4.75 \\
\cline { 2 - 4 } & Japan & 74.38 & 0.60 \\
\cline { 2 - 4 } & Australia & 49.29 & 0.40 \\
\cline { 2 - 4 } & Others & 725.42 & 5.87 \\
\cline { 2 - 4 } & Total & 12347.77 & 100.00 \\
\hline
\end{tabular}

Source: BATEXPO, 2009 
Table 8. Primary problems of Garments Industries

\begin{tabular}{|l|c|c|c|}
\hline \multicolumn{3}{|c|}{ Primary Problems } \\
\hline Problems & High & Medium & Low \\
\hline Labour unrest/strike & $100 \%$ & - & - \\
Machinary problem & $100 \%$ & - & - \\
Quota problem & $80 \%$ & $20 \%$ & - \\
Inefficient workforce & $60 \%$ & $40 \%$ & - \\
Raw materials & $60 \%$ & $40 \%$ & - \\
Poor government policy & $60 \%$ & $40 \%$ & - \\
Licensing problem & $20 \%$ & $20 \%$ & $60 \%$ \\
Marketing problem & $20 \%$ & $60 \%$ & $20 \%$ \\
\hline
\end{tabular}

Source: Zafour 2009

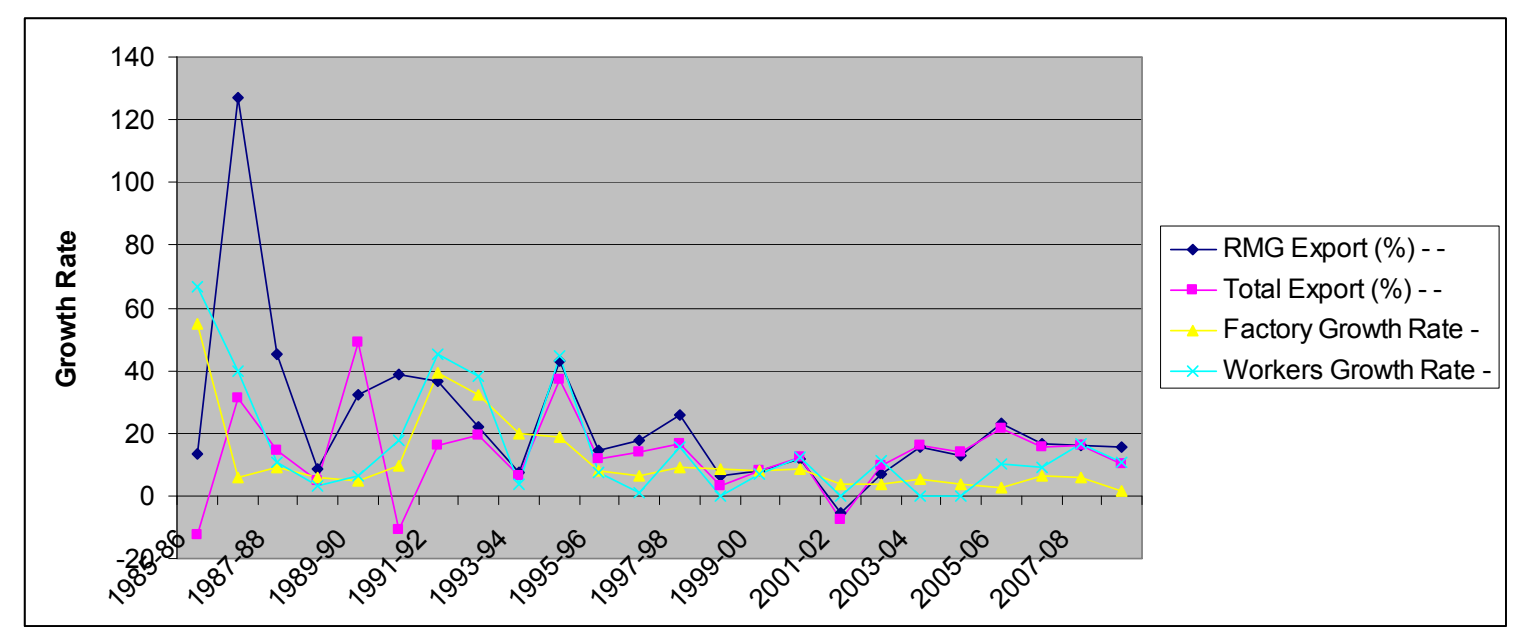

Figure 1. Comparative chart of growth rate of RMG export, total export, number of factories and workers 